\title{
Great Expectations? Childhood, Family, and Middle-Class Social Mobility in Nineteenth-Century
} England

Christina de Bellaigue

Exeter College, University of Oxford

Christina de Bellaigue, Exeter College, Oxford, OX1 3DP

Christina.debellaigue@history.ox.ac.uk

Christina de Bellaigue is Associate Professor in History at the University of Oxford. She is the cofounder of interdisciplinary The Oxford Research Centre for the Humanities (TORCH) research network 'Rags to Riches: experiences of social mobility' which explores qualitative approaches to the history and study of social mobility. Her current research explores the fortunes of French and English families of the industrial bourgeoisie over four generations, shedding new light on the relationship between gender, family and social mobility in the nineteenth-century. 


\title{
Great Expectations? Childhood, Family, and Middle-Class Social Mobility in Nineteenth-Century England ${ }^{1}$
}

\begin{abstract}
Existing histories of social mobility have focused on adults and on measuring the achievement of individual upward mobility. However, children were central to mobility strategies. Using the papers of the Heywoods of Bolton, this article examines how the families of the industrial middle class endowed their offspring with the goods and character needed to secure their social standing, highlighting the emotional intricacy of these processes. It demonstrates that such families conceived of social mobility as a familial project and that rather than pursuing upward mobility, their chief objective was to guard against social decline.
\end{abstract}

Keywords: childhood, social mobility, inheritance, family, aspiration, goods, character

In May 1852, the Bolton cotton-manufacturer Robert Heywood wrote to fellow industrialist Henry Leigh. Heywood's intention was to ask if Leigh might take in Robert McKeand, Heywood's eighteenyear-old nephew, as a junior in his business. McKeand - his uncle thought - needed work that would help him "secure the steady business habits so important in the commencement of active life". ${ }^{2}$ The apprenticeship would mark the final stage in a long process of instruction, education and training over which Heywood had kept a close watch. Sixty years later, Mary Haslam - a suffragist, active member of the Bolton Board of Guardians and Heywood's daughter - looked back on her life and reflected on her role as a mother: "the question of education perplexed me much...I have often thought I should like to know what the children themselves thought, and whether they considered they had the best chance". ${ }^{3}$ For Robert Heywood, the careful management of his nephews', niece's, and later his own children's education and upbringing was a key concern, occupying much of his correspondence. ${ }^{4}$ The education of Mary Haslam's children remained one of the central preoccupations of her very active life. ${ }^{5}$ In different ways, both expressed a conviction that it was the education and training received in childhood that would ensure that the next generation "had the best chance". Both felt themselves responsible for the continued prosperity and advancement of the next generation of Heywood and Haslam daughters and sons, and also for the success of the family as a whole. This article examines the efforts made by Heywood family members on behalf of their children to highlight how, in the nineteenth-century, children might become the beneficiaries of strategies to ensure their own social mobility, but were also the repositories of wider familial expectation and aspiration. 
Existing historical studies of social mobility tend to be based on large-scale analyses that plot individual - usually male - trajectories up and down the social scale. ${ }^{6}$ They use the occupational status achieved in adulthood as the point at which to gauge intergenerational social mobility. To the extent that children have been considered, it is their absence - as a result of family limitation - that has been focused on. J.A. Banks, for example, noting declining family size among the English middle classes, maintained that family size limitation was partly the result of middle class aspirations to secure a high standard of living and provide their children with the education required for them to do the same. ${ }^{7}$ As feminist demographers have contended, such arguments about fertility - and the idea of "family strategy" more generally - abstract families from their emotional context and suggest that families will operate rationally on the basis of judgments about relative costs and benefits. ${ }^{8}$ This kind of analysis can also play down internal power dynamics and gendered hierarchies within families, and tends to deny agency to those involved, particularly under-recognising women's ability to influence decisions about family life. ${ }^{9}$ Exploring the efforts of the Heywood parents of both sexes with respect to the children they were surrounded by reveals the complexity of the decision-making processes within family life and brings to the foreground the experiences of children concealed by the demographic analysis of family limitation strategies.

The leading sociological analyses of social mobility, too, tend to abstract individuals from their familial and emotional context. By focusing principally on male occupational mobilities, they also neglect the experiences of women. ${ }^{10}$ Neither do existing studies, with the exception of important work by sociologists like Steph Lawler, shed much light on social mobility as a process, or on the experience of being socially mobile. ${ }^{11}$ Much of the scholarship also tends to assume upward social mobility as a universal aspiration, and to focus on individuals. Thompson, Bertaux and BertauxWiame, however, highlight the ways in which the family is central to the experience and process of social mobility: "mobility is as much a matter of family praxis as individual agency, for it is families which produce and rear individuals with specific characteristics and social skills, endowing them with their original moral and psychic energy and with economic, cultural, and relational resources" ${ }^{12}$ They argue that experience of social mobility is relational and involves the complex negotiation of emotions and expectations.

This article draws on the work of Lawler and Bertaux et al and uses a family-biographical approach to examine the experience and practice of social mobility among the nineteenth-century middle classes by focusing on the understudied relationship between childhood and social mobility. My focus is on the industrial middle class because it was in reference to this group that nineteenth- 
century ideas of the 'self-made man' and stories of 'rags to riches' were most clearly articulated, and this group who were perceived as embodying the new fluidity of nineteenth-century society. ${ }^{13}$ The Heywoods were a family typical of this industrial middle class and were prominent in business and public life in Bolton from the early nineteenth to the early twentieth century. They were committed Unitarians, thus joining the substantial proportion of non-conformists among cotton-manufacturing families. ${ }^{14}$ Though somewhat unusual in terms of the prominence of their commitment to Bolton's public life - Robert Heywood was the town's first mayor (1839-1840), and was followed in this office by his son John (from 1903-1905), and Mary Haslam was the first woman member of the Board of Guardians) - and distinctive in the volume of their surviving personal papers, the social and economic profile and trajectory of the Heywood family otherwise correspond closely to the broad patterns identified by prosopographical and local studies of Lancashire manufacturers. ${ }^{15}$

My focus in this article is particularly on the childhood and parenthood of the two middle generations of the Heywood family. Robert Heywood (1786-1868) headed the family's cottonmanufacturing and bleach-work enterprise, having become his father's partner in 1803. Hannah Heywood McKeand (1796-1848), Robert Heywood's sister, was educated, like her brother, at Mr Holland's school in Bolton. In 1822, she married John McKeand (1751-1845), also a cottonmanufacturer. They had three children, John McKeand jnr. (1826-c.1870) Mary McKeand (18321880), and Robert McKeand (1835-1868). In the long period before his late marriage to Elizabeth Shawcross (1816-1898) in 1849, and continuing on after their mother's death that same year, Robert Heywood played a significant role in the upbringing of the McKeand children. Both nephews would enter industry through Heywood enterprises and Mary McKeand married a cousin of Elizabeth's, a cotton merchant. Robert and Elizabeth Heywood had three children themselves, John Heywood (1849-1910), Mary Haslam (1852-1922) and Robert Heywood jnr. (1856-1921). John Heywood became a barrister, and like his sister, went on to be prominent in Bolton public life. Robert jnr. eventually took over the Heywood bleach works. ${ }^{16}$

As this brief summary of the family's mid-nineteenth century history might already suggest, business and family were inextricably intertwined for the Heywoods. A growing body of scholarship exploring the interconnected histories of property, inheritance, business and family among the mercantile and industrial middle classes demonstrates that, in the words of Alastair Owens, "the family needs to be seen less as an influence on business activity and more as its raison d'être."17 Thus, the pursuit of success in business might be a familial project, frequently embarked upon in a prudential, rather than an acquisitive spirit, with success defined as security rather than large profits. The picture 
gleaned from the Heywood family papers builds on the insights drawn from these new histories of property and business, and echoes the findings of R.J. Morris's research on Leeds, suggesting that property strategies across both the business and professional middle classes were predicated on the need to preserve against death, illness and business failure. ${ }^{18}$

Thus far, however, like the history of social mobility, the new business history has not paid much specific attention to children. Nor have historians of childhood been much interested in the role of children in enterprise or in social mobility - the latter seeming a particularly surprising omission given the prominence of children in the great nineteenth-century fictions of social mobility, like Pip in Dickens' Great Expectations (1860-1) or the Tullivers in Eliot's Mill on the Floss (1860). ${ }^{19}$ Yet for families like the Heywoods, children were central to family mobility strategies. They were the recipients of intergenerational transfers of economic, social and cultural resources, of heartfelt lessons about the "steady habits of industry", and they were frequently the carriers of adult aspiration. This article asks what mechanisms were used to make these intergenerational transfers of capital. It analyses how these burdens of expectation were conveyed by the older generation and the strategies they employed to ensure the young fulfilled those hopes. At the same time, it seeks to extend and nuance our understanding of family strategies by highlighting the ways in which these processes of transmission were often intensely emotional, involving contestation and competition as well as co-operation. It draws on recent work by Joanne Bailey and others engaging with the history of emotion in family life and with the work of Andrew Popp who contends that exploring the emotional world of entrepreneurial families can be a way to "rehumanise the economic". ${ }^{20}$

By focusing attention on children in analysing the history of social mobility, this article builds on the insights of historians of enterprise who have revealed the ways in which the needs of family intersected with and influenced business decisions. At the same time, it provides a lens through which to explore the experience of social mobility as a complex familial and relational project, involving women as well as men; a way to examine social mobility as "family praxis". Attending to the ways in which children were both the objects and carriers of intergenerational goods and aspirations, in a period when childhood was being reconceptualised as formative and of critical importance, and to the emotions expressed by those seeking to provide for them, helps us to rethink some of the categories and assumptions of social mobility research. ${ }^{21}$ Significantly, focusing on childhood calls into question the idea of upward mobility as a key objective. Studying the correspondence and papers of the Heywood family - and particularly the ways in which they provided for their children - suggests rather that they sought principally to insure their offspring 
against downward mobility. ${ }^{22}$ Rather than seeking social advance per se, the correspondence of Hannah McKeand and Robert Heywood, and the efforts they made to provide for their children, suggest that their principal, and anxiously-pursued, objective was security. Focusing on childhood then, draws attention to the ways in which, rather than ambitiously seeking upward advance, the families of the industrial middle class in the mid-nineteenth century, might instead anxiously be securing themselves against the possibility of decline. This in turn calls into question the appropriateness of the language of 'social mobility' to describe what was, in effect, a set of practices which were aimed, rather, at ensuring social stability.

Pierre Bourdieu's identification of different capitals - economic, social, and cultural - has been effectively deployed by historians and sociologists interested in processes of intergenerational transmission, social reproduction and social mobility. ${ }^{23}$ Bourdieu argues that class status (and inequality) are reproduced by the focused distribution through families and educational institutions of economic capital (financial assets, property), of social capital (networks of acquaintance and recognition constructed through sociability), and of cultural capital (education, cultural knowledge, style of dress and speech). However, Bourdieu's analysis does not take sufficient account of the emotional character of these processes of distribution. ${ }^{24}$ Nor, my research suggests, does it adequately capture the intertwined social, cultural and financial resonances of what families sought to transmit in the nineteenth-century, or the intricacy of these transactions. Moreover, even as the Heywoods often conceived relationships in business terms and emphasised the need to pass on resources to the next generation, this vocabulary of multiple capitals was not one which they would have recognised. Influenced by John Tosh's defence of "listening for the intended meanings", I will adopt a nineteenth century terminology of 'Goods' - by which is meant the often measurable goods of wealth, property, connections and educational status, and 'Character' - by which is meant reputation, habits, and values to explore the Heywood family's experience and practice of social mobility. ${ }^{25}$ For the Heywoods, as for many nineteenth-century families, the testamentary process and the transmission of 'Goods' - which might have moral and well as emotional value as well as economic benefits - was a subject of considerable interest and importance. Their letters are full of the details of wills and division of property between friends and family members, also, of course, a notable preoccupation of the nineteenth-century novel. ${ }^{26}$ 'Character' was also a key term for the Heywoods and their peers. In a period which was perceived by many as a time one of social fluidity, force of character was considered an important quality, and one which it behoved the older generations to foster in the younger. ${ }^{27}$ Evangelical ideals of manliness encapsulated contemporary ideas of character which were fostered through work conceived as moral and through the home 
conceived as 'the school of character'. ${ }^{28} \mathrm{~A}$ reputation of good character was also a key lubricant for business and social interaction; more generally, the term was increasingly used to invoke a set of moral qualities which were valued as a public good. ${ }^{29}$ For the Heywood family, the idea of fostering 'character' in the next generation took on a particularly Unitarian inflection, reflecting a denominational emphasis on human perfectibility and on the importance of economy and reliability in the business of everyday life. ${ }^{30}$

\section{l) Goods}

The most obvious sign that children were the objects of mobility processes was that family members went to great lengths to provide for future generations. In different ways, the men and women of the industrial middle classes sought to transfer material, social, and cultural goods to their children. Provision for his children, but also for his sister's offspring, was a key objective of Robert Heywood's business activities and investments. Soon after Heywood's first son - John - was born in 1849, Heywood rewrote his will to ensure the distribution of these different resources between his own children, his sister's children - and his putative grand-children and great-nephews and nieces. ${ }^{31}$ Indeed, it's notable how much of each of the wills he wrote was concerned with securing the position of future generations, including those yet to be born, a phenomenon partly explained by the need to provide against the possible untimely death of his heirs. The 1849 will is a long document because it built in multiple protections and securities to ensure that the transfer was harmonious and equitable. Heywood's approach conforms to the pattern whereby middle class entrepreneurs practiced a kind of partible inheritance..$^{32}$ It also fits with the characterization of property strategies among the Leeds middle class as "structured by the potential for disaster". ${ }^{33}$ Such provisions reflected Heywood's awareness of the fragility of life and health, which might have been later reinforced by experience, since the gap between the birth of John in 1849 and that of Mary in 1852 may indicate that the Heywoods had suffered loss or miscarriage, as suggested by a reference in Mary's memoirs to Elizabeth understanding Mary's grief at the loss of her young daughter. ${ }^{34}$ They also manifested an awareness he shared with Hannah of the instability of business and property, with several letters in the correspondence documenting the failures in business of colleagues in the vicinity, and the difficulties for neighbouring families and other branches of the Heywood family when no provision was made for the distribution of property. ${ }^{35}$ 
Morris's study of Leeds, like Owens's work on 'wealthfare' - the process whereby middle class families used inheritance strategies to provide for family members - both suggest that the Heywoods were not unusual in arranging the disposal of their property in this way. ${ }^{36}$ Thomas Piketty's work has drawn attention to the ways in which such mechanisms for the intergenerational transfer of wealth sustained patterns of inequality throughout the nineteenth-century and beyond. ${ }^{37}$ But paying close attention to their correspondence and legal documents also highlights both the possible emotional resonance of these strategies for parents thinking of their children, and the tensions that arose from what might be provisional and contingent legacies. First, the act of willwriting itself might be draining, involving as it did the negotiation of responsibilities to family members and the conjuring of uncertain futures; it was also an act that needed to be frequently repeated as the contours of the family changed. ${ }^{38}$ In 1847, Hannah wrote to Robert in response to his request that she rewrite her will, describing the complex back and forth process of consultation with the solicitor, and concluding "I hope it will now be satisfactory to all but let me hear from you, I shall get it signed as soon as I have an opportunity for I am quite tired of it". ${ }^{39}$ Such laborious processes were essential to ensure that the Heywood offspring were provided for, and not "left pennyless" like Hannah's Smith cousins, a prospect she greatly feared.$^{40}$ Hannah's correspondence evokes vividly the anxiety, frustrations, and boredom, that these negotiations might involve.

The correspondence between Hannah McKeand and her brother is also particularly revealing in respect of the tensions and emotions that might be aroused by the need to ensure the safe transmission of goods. McKeand's son John was, until 1848, one of the principal beneficiaries of his uncle's will. This was of great importance to Hannah, because whereas Robert's business had prospered, the McKeand family had had less success. It is clear from her letters that her desire to protect this legacy, dependant on preserving her brother's good opinion of his nephew, was a key preoccupation and a source of considerable anxiety. Thus, in December 1847, she wrote - following a disagreement between Robert and her son - that

I am sorry if he expressed himself too strongly and I think he is too, for I believe he does not want to offend you if possible... I hope however all is comfortable again it pains me very much to hear otherwise. ${ }^{41}$

It was imperative for Hannah to smooth over the conflict in order to secure her child's future. While her emphasis on the pain and distress that the disagreement had caused both her and her son might have been partly rhetorical, designed to appease Heywood's offended sensibilities, the repetition of such emotions throughout the correspondence do suggest an underlying tension and anxiety about these issues. 
To the next generation, Robert Heywood transferred not only commercial and financial capital, but property and the social standing that came with it. By the 1850s, he had accumulated enough through inheritance, business, and his new wife's dowry, to think in terms of diversifying his investments, purchasing a small estate called The Pike and building a house on the property, as well as some rental properties. ${ }^{42}$ In this, he fell in line with the pattern identified by Howe whereby from the 1840s, Lancashire cotton-manufacturers tended increasingly to employ managers for the daily running of their businesses, and to express their economic confidence through the purchase of property and the adoption of more leisured life-styles. ${ }^{43}$ It was a strategy echoed by middle class industrialists and businessmen in the Midlands too. ${ }^{44}$

The example of Robert Heywood suggests that this also had implications for the family's social standing, and was particularly directed toward the children of the family. However, the acquisition of such estates was not a matter of simple aristocratic emulation and aspiration as has been suggested by some. ${ }^{45}$ Rather, it was undertaken with the same prudential focus as the careful testamentary distribution of goods among family members, with an eye to securing the next generation's position rather than providing a foundation for their upward mobility. Thus, in 1851, writing about his plans to purchase The Pike, Heywood directly attributed the decision to the appearance of his son John on the scene: "I may say, this little fellow has induced me to purchase an estate...and am going to build a house".${ }^{46}$ Further highlighting the importance of the house and estate and its place in what he hope to transfer to his children, Robert Heywood's diaries around the time of the purchase - usually extraordinarily un-illuminating - are suddenly filled with entries documenting the process of the purchase and then the building of the house. ${ }^{47}$ But Heywood's letter also reveals that this was not about seeking ascension to the gentry; mentioning the cost of the new house he further noted the future rentable value of the property, which could be turned to good account should the need arise. ${ }^{48}$ In the event, this was not required and as planned, after Heywood's death, The Pike went to his son John, who, rather than entering cotton-manufacturing or the bleachworks, attended Cambridge and became a barrister. John Heywood's connection to Bolton was thus sustained through The Pike, from which he successfully launched his campaign to become mayor of the city. Again, rather than furthering an aristocratic aspiration to transcend the Bolton middle class, the purchase and transmission of The Pike estate instead provided John Heywood with a secure position within Bolton. Likewise, when in 1833, John McKeand Snr. had made a similar move and built a new property in Southport, children were to the fore. McKeand boasted in a letter to Heywood that it was his eldest son John McKeand, then only two, who had laid the first bricks. ${ }^{49}$ The 
symbolism was clear. Investing in property, building new houses, Heywood \& McKeand Snr were also underpinning their children's social standing in the local community and taking pride in the bricks and mortar they would hand on.

Robert Heywood also set great store by the value and meaning of the other goods he sought to transfer to his children. His will made careful provision for the transmission of his extensive library, engravings and other artworks. Heywood attached particular significance to his Bowyer Bible - an expensive engraved edition of the bible. A special codicil drawn up on 1857 specified that this bible should go to John Heywood and noted that "I hope [it] will remain in the family during many generations" ${ }^{50}$ The Bowyer Bible was a symbol of Heywood's standing as a leisured gentleman, of his children's membership of a cultured provincial elite, and of his hope for their continued membership and good standing within this elite. ${ }^{51}$ His pride in the object, and what it connoted, comes through clearly, and it would seem - from the similarity in attitude between Heywood and McKeand snr., and the close association they drew between their sons and their houses - that both shared a sense that the safe transmission of goods whether in the form of land or valuable artefacts was a masculine responsibility, and a sign of good fatherhood.

In the Heywood family, gender seems to have influenced the kinds of goods that the men and women of the family sought to transmit. Hannah McKeand was intimately involved with the day-today management of resources, aware of the family's business ventures, and managed the relationship between her children and their uncle in order to consolidate their inheritance, though in these areas, she appeared to defer to Robert as the male head of the family. Her letters, however, and later those of Elizabeth Heywood, suggest the ways in which the Heywood women might additionally see themselves as particularly responsible for perhaps more prosaic but equally significant legacies to their children. Both were continually preoccupied with their children's health and physical development. Unsurprisingly, given rates of infant and child mortality, health and physical well-being were valuable goods. ${ }^{52}$ At the same time, McKeand was keen to ensure that her children were provided with the goods needed for day to day security. Thus, during a period when she was ill herself 1845, she wrote several times asking Robert to ensure that a Mrs Dean of Bolton would take care of "my dear children's clothes and other little comforts they may require which you may not think of". This was about childcare, but it was also about respectability, as a second letter, in which she emphasised again the importance of "putting things in order for the children" but also the proper care of their clothes and appearance, underlines..$^{53}$ 
'Connection' (what Bourdieu would term 'social capital') was another, less tangible 'good' that parents of both sexes sought to transfer to their children. One of the most obvious ways in which this was generated and handed on was through the networks of family, friends, and religious and political association that the Heywoods fostered. The breadth of Robert Heywood's correspondence is testament in itself to the importance of maintaining such relationships, and the tensions that might arise when it was threatened. Thus, several of Robert Heywood's angriest letters to his elder nephew concern the importance of pursuing appropriate friendships, and avoiding behaviour which would endanger those relationships. In 1844, having discovered that John McKeand was in the habit of smoking, his uncle wrote "to express my surprise and very great dissatisfaction". This was "a nasty disgraceful habit" in Heywood's eyes, but most damningly, he added that "no such habits are to be found among the really respectable youth in our connexion, the Leighs Gollands and Shawcrosses and I must insist on your part that it be entirely abandoned" ${ }^{54}$ In a context where business success depended on the trust of investors, it was crucial that the younger generation understand the importance of maintaining the family's reputation and social standing and inherit these valuable connections..$^{55}$

Relations between Robert Heywood and his own children seem to have been less tense than with his nephew, perhaps partly because he died while John, Mary and Robert were still young and malleable. Nevertheless, Haslam's autobiography reflects further ways in which their father sought to foster and transfer social capital; networks, reputation and public position were also fostered through engagement in local civic life. Heywood was very prominent in Bolton's religious, civic and philanthropical organisations..$^{56} \mathrm{He}$ also sought to foster the habit of civic engagement in the next generation. Mary's recollections attest to a family atmosphere and family practices which emphasized the importance of these activities, partly through awareness of their father's absence at public meetings, and partly because the children were expected to be present and attentive during the visits of the many people who sought out Heywood by virtue of his position. She recalled listening to conversations about public events, the end of the Crimean War, and the American Civil war and suggested that "this blending together of young and old, and the former hearing the grownups conversation, lead to a taste in public questions and an interest in the latter which developed in later years" ${ }^{57}$ While her autobiographical account clearly serves to legitimate Mary's own path into public life, the careers of the Heywood children do suggest that his offspring internalised their father's commitment to public life: Mary Haslam became the first woman on the Bolton Board of Guardians, founded the Girls High school, was a prominent local suffragist and a significant member 
of the Guild of Help. ${ }^{58} \mathrm{~A}$ family tradition of civic activity, and connections, fostered in childhood, consolidated the Heywood family's position within the local industrial elite. ${ }^{59}$

Education and instruction constituted a further 'good' that the Heywoods and McKeands sought to transfer to their children. Education blurs the boundaries between Bourdieu's different forms of capital in the ways in which it might both confer social standing and prestige and extend and reinforce valuable connections. It was also, as will be suggested below, a key mechanism for the transmission and nurturing of 'character'. Focusing for now on instruction as a 'good', it is clear that for the Heywood family, education was a valuable commodity, and one they were willing to pay for, while chafing at the cost of many other things. This was an investment in the most direct sense - in the 1790s and 1800s, John Heywood snr was paying $£ 12$ p.a. to educate Robert and Hannah at $\mathrm{Mr}$ Holland's school. ${ }^{60}$ In the 1840 s, Hannah was prepared to pay c. $\mathbf{5 3}$ per year on a guaranteed annual income of about $£ 300$ for Mary's schooling. ${ }^{61}$ The cost might also be emotional - Hannah McKeand greatly lamented being parted from Robert in the 1830s while he attended school in Manchester, and, like her niece in the 1890s, agonized over the choice of institution for her children. ${ }^{62}$ However, these were costs that both considered worth paying. Hannah McKeand's concern for her children's education, and Robert Heywood's supervision of it, is a key theme of their correspondence. McKeand was continually asking herself how best to ensure that her children "have every advantage of instruction". ${ }^{63}$ The archive includes multiple letters seeking information on different governesses and schools so that she could decide on the most appropriate course.

In the history of education, middle class interest in schooling in this period has often been attributed to social ambition. This reflects in part frequent contemporary criticisms of girls' schools which offered archetypal farmers' daughters 'an education above their station' ${ }^{64}$ Histories of the public schools have argued that their attraction was that they provided a 'conspicuous education' which offered a mechanism of social distinction to upwardly mobile middle class parents, a perspective shared by studies of the apparent decline of the 'industrial spirit' and the gentrification of the entrepreneurial elite. ${ }^{65}$

These analyses misrepresent the serious interest many middle class parents took in their children's development, evident - in the Heywoods' case - from the care they took in selecting instruction for their children, and from the attention they paid to their children's academic progress throughout their schooling (Robert Heywood's often sketchy diary provided details of John's beginning school and starting to study Latin). ${ }^{66}$ The Heywood example also suggests that the role of schooling in social 
mobility was less clear cut than the existing historiography suggests. As will be discussed below, none of the Heywood children of this generation was sent to a public school, rather they were educated at carefully chosen Unitarian institutions, local to the North West, which offered the boys instruction in Classics, but also in 'modern subjects' of book-keeping, mathematics and modern languages. ${ }^{67}$ The Heywood children's instruction was directed more towards ensuring their ability to prosper within the local economy than towards any aristocratic ambitions.

Yet belief in the intrinsic and practical value of education could, and did, co-exist with more tactical concerns. Hannah McKeand clearly did see education in terms of social competition, as well as something of intrinsic value: for example the wrote in 1847 that she "hoped that Mary might be quite equal if not excel her friends and companions in every branch of learning" ${ }^{68}$ The education that she had received, and that she sought for Mary, was the conventional one, derided by many contemporary observers. As Davidoff \& Gunn have contended, in the middle classes, women embodied cultural capital in their dress, and deportment - musical training, dance and French were important signifiers. ${ }^{69}$ The Heywood correspondence contains discussion of Hannah's own musical instruction, and then lengthy exchanges concerning the provision of pianos, dance and French lessons. These skills might not necessarily provide the adult Mary with the means to earn an income, but Hannah McKeand was well aware of the social value of her daughter's education. Her efforts to pursue "every possible opportunity" for Mary reflected McKeand's belief that such training would secure her daughter's future position, and might preserve her from downward mobility. ${ }^{70}$

The Heywoods, McKeands and Haslams made every effort to transfer 'goods' - investments, property, connections and educational qualifications - resources to the next generation in order to ensure their social stabliity. Hannah McKeand sought to provide for her children's future by cultivating good relationships with those around her, Robert Heywood sought to provide for his by diversifying his investments, and, as his business grew, by buying up property, and consolidating relations with local elites. But these were not cold calculations or simple transmissions, they involved complex emotions and might provoke tension. The Heywood papers suggest an undercurrent of anxiety to all of their efforts. Investment in land and estates, the cultivation of extensive networks, might be an expression of a desire for security as much a sign of confidence. ${ }^{71}$ Educational attainments and skills provided a further insurance. At the same time, they sought to transmit to their offspring the attributes and values - the 'character' that would ensure their security and success. 


\section{II) Character}

As suggested above, the educational choices made by the Heywoods for their children reflected not only an effort to provide their offspring with the 'good' of instruction. They also reflected a belief in the importance of education and its role in the fostering of 'character'. As John Tosh demonstrates, Evangelical parents and educators sought to foster in young men a notion of 'character' which incorporated self-discipline, diligence, self-restraint, and notions of duty and responsibility. ${ }^{72}$ In the Heywoods' case, this interest was perhaps amplified by their Unitarianism, many Unitarians having a particular belief in the importance of education for both girls and boys, and being resistant to the attraction of the public schools. ${ }^{73}$ Indeed, Robert Heywood was categorically opposed to a public boarding school education on the grounds that such institutions might lead to 'excesses'. ${ }^{74}$ The stakes in such decisions were high. This is particularly clear from the letters of Hannah McKeand. She was often anxious about the decisions she was making, second-guessed herself repeatedly, and sought reassurance in her brother's approval. Her emotional engagement in these questions echoes that of Mrs Gaskell, in whose diary accounts of her daughter's education Uffa Jensen has argued the most pervasive emotions were love and anxiety. ${ }^{75}$ Such feelings were intrinsically intertwined in a context where parental influence was given increasing weight - over ideas of original $\sin$ - in the formation of children's character.

With education of such importance for the development of children's character, schools were chosen with care. The McKeand sons were thus sent to the leading Unitarian institutions: John McKeand to the Revd John Relly Beard's school in Manchester, and Robert McKeand to the school of the Revd Henry Green in Cheshire. ${ }^{76}$ Mary Haslam was sent to two influential institutions for girls, a Unitarian school run by Louisa Carbutt in Knutsford, and then to Mrs Lalor's school in London, (another Unitarian institution, also selected by Mrs Gaskell for one of her daughters). ${ }^{77}$ The Heywood sons were sent to Bolton School, which was then a non-conformist institution. ${ }^{78}$ Evidence from Mary's recollections provides an insight into the particular focus on character-building of these establishments. She remembered that at Miss Carbutt's, "The teaching was excellent and intelligent... A law to yourself was one of her favourite phrases, and that being so, ordinary rules and regulations became commonplace, and, as such hardly existed" and attributed her achievements in public life "to her who was the inspiration of my youth (leaving aside the more direct influence of the home" ${ }^{\prime 79}$. These establishments were intended to foster self-discipline and to endow the 
Heywood children with the psychological resources they needed in order to sustain their social position through public life.

Diligence and hard work were a key element of what was to be learned at school. While the education Mary McKeand was provided with might be described as ornamental, she was nonetheless expected to work hard at her lessons. A letter of 1849 reveals that her uncle had been unimpressed with Mary's complaints about having to do drill at school. ${ }^{80}$ Judging by the correspondence, the principal objective of Robert Heywood's own schooling in the 1790s was also to instill in him the habit of hard work. Thus in 1796, his teacher John Holland reported that "If Robert Heywood either played less or devoted some certain portion of his time at home to prepare himself for school he would probably make greater progress in useful knowledge" ${ }^{81}$ Requests for "increased diligence" continued to dominate Robert's reports until 1800, suggesting a certain resistance to his parents' and teachers' recommendations.

When it came to the education and training of his nephews, Robert had similar expectations, as did their father. Any sign that they were not working hard was immediately commented on. ${ }^{82}$ The pressure continued once they were sent out to gain experience in business. Thus in May 1842, Hannah reported that though her son John had been permitted to take a fortnight's holiday from the Salford Bleachworks, "his father thinks it too long for him to be idle" and she asked Robert to ensure that it was curtailed. ${ }^{83}$ This would have been in line with Robert's thinking, for when he wrote to arrange John's lodgings in Salford, he specified that "I think it will be as well for my nephew to be at the Crescent [bleachworks] every morning precisely at $8 . . .1$ should however particularly desire that he should be called at six so as to have an hour to be spent usefully in reading $\& c^{\prime \prime} .{ }^{84}$ Another flurry of activity in Robert Heywood's generally dull diaries marks the period when John was living in his house: Robert recorded the time at which John got up every day. ${ }^{85}$

Similar recommendations were made when Robert McKeand was placed in business. Heywood had begun training Robert early in the necessity of early rising, providing him - as a 10 year old - with a hen whose eggs he was expected to collect first thing. Robert reported to his uncle that "I do not forget the rules, I attend to the birds and I have been up before it has struck seven every morning". Later letters continued to report on the hens' laying. ${ }^{86}$ These strategies reflected a belief in the importance of diligence. They also pointed to an emphasis on the importance of using time wisely, which, as Bailey suggests, fits with a middle class tendency to see accounting for one's time as a means to assert one's own worth ${ }^{87}$. The Heywoods and McKeands were keen to nurture in their 
children the habits and values that would ensure their future status, prosperity, and security in society.

Home life and family life more generally operated in ways intended to transmit, though indirectly, a sense of duty and responsibility. Mary Haslam recalled that "duties were laid down and habits formed, in an indirect fashion".$^{88}$ The lessons of prudence and saving were also taught by other means: the Heywood children were given pocket money which they were expected to manage, and a glimpse of Robert Heywood's stern injunctions on the need to be abstemious can be seen in the complaints of his much younger wife, in response to what seem to have been letters reproving her for her spending. ${ }^{89}$ For Robert Heywood, these were crucial aspects of character to be fostered. In a long letter to an American cousin he detailed the sad fortunes of another branch of the family, who had not been so well taught, including James who "was much indulged by his mother, and has turned out a very idle drunken character"; this cousin was contrasted to William Holden, who was employed by a neighbouring cotton spinner "and I believe has saved some money". ${ }^{90}$ The stakes were high; those who did not develop good characters were at risk of failure. As an earlier letter noted when business in Bolton was bad: "some have failed through negligence, others by the grossest misconduct" ${ }^{91}$ In this analysis, business failure reflected failure of character, and would inevitably result in social decline.

To Robert Heywood's chagrin, his nephews and niece did not share their uncle's abstemious habits or diligence at work, a fact which frequently provoked frustration and disappointment. In 1842, he found it necessary to reprimand John, who had not been rising early as expected, a pattern repeated when Robert went into apprenticeship; in 1844, he wrote again to John to complain about his smoking. ${ }^{92}$ Heywood was particularly exercised about his nephews' dress and comportment, emphasizing in 1844 that John should

apply only to J. Chorley for any future clothes you may require and take care they are only such as shall be neat and reasonable. You can never be too clean or neat in your habits either in business or parties of pleasure but anything approaching to a fop is despised by one and totally irreconcilable with the other.

Here, he echoed an earlier letter to some as yet unidentified adult cousins whom he reproved in irritation for "dressing above their station" whilst also expecting their father to support them. ${ }^{93}$ Such examples suggest the ways in which children were expected not only to absorb the lessons of diligence and application, but also through appropriate behaviour and physical discipline, to embody the family's values and expectations. It was not only children's habits, but also their bodily 
comportment, which would shape their social destiny. As Gunn has suggested, the cultural capital of the English middle class "has been transmitted in important measure somatically, in bodily form". ${ }^{94}$ As the reference to "dressing above their station" emphasises however, the aspiration was not for ascension into the ranks of the aristocracy, rather it was for conformity and respectability within the middle class.

Robert Heywood's letters suggest that he considered the socialization of his nephews though the promotion of appropriate behaviour and physical comportment, to be one of his key responsibilities. They also point to the ways in which the effort to transmit values and behavioural conventions might be points of particular tension. While Mary Haslam noted that the lessons of duty were imbibed indirectly in the Haslam family, she also noted that she kept many of her thoughts to herself, lest the adults of the family be shocked. ${ }^{95}$ Once at Mrs Lalor's school, she grew more resistant: "the evening before I left, I was taken into Mrs Lalois [sic] private room and told that I should regret all my life the way I had set myself in opposition to all they had tried to do for me" ${ }^{96}$ As we have seen, Heywood's letters attest to conflict between Uncle and nephew and to the anger and disappointment Heywood felt when they did not live up to his exacting standards. Similarly, Robert Heywood's letter to Mary McKeand's complaints about drill suggest his exasperation at her lack of application. Such efforts were required, however, the social standing and security of the family depended on the success of Hannah McKeand and Robert Heywood in ensuring that the Heywood children shared and embodied the family's values.

\section{Conclusion}

This article has suggested some of the ways in which children might be central to the mechanisms of social mobility deployed by the families of the industrial middle classes in nineteenth-century England. The Heywoods and McKeands were not unusual. The methods by which they sought to transmit goods and character to their children were common among the families of the Lancashire cotton-manufacturers, and find echoes in the property strategies identified adopted in families of the industrial and commercial middle classes more widely. ${ }^{97}$ Business, property, investment, inheritance, social and cultural capital were all managed to ensure the security of future generations. The efforts both of fathers, like Robert Heywood, who sought to transmit property, estates and the characteristics required for success in business to the next generation, and of mothers like Hannah McKeand, more directly concerned with ensuring the health and well-being of their children (while also seeking to foster the good relations on which their material inheritance depended) reflected a perception of their position as fundamentally insecure; underpinning it all 
was a nagging sense of anxiety. These families of the industrial middle classes did not have great expectations of joining the ranks of the aristocratic elite, their principal objective was to shore up the position of their children in order to insure against downward mobility.

As suggested in the introduction, recognising the extent to which it was an effort to secure social stability, rather than a focus on social ascension, that informed the family strategies of the industrial middle classes calls into question the appropriateness of the language of social mobility to characterise these practices. I would argue that it is nonetheless important to understand these practices as variants of social mobility strategies. The history and analysis of social mobility has sought to shed light on the fluidity of society and class structure, to examine the extent to which societies have been characterised by equality of opportunity. The strategies employed by families like the Heywoods were designed to preserve them against that fluidity, to protect their offspring from the threat of greater equality of opportunity. In a very different context, Verhoeven and Palmer have argued that the focus of gender equality research should be the practices of gatekeeping and social closure deployed by those who seek to preserve the status quo. ${ }^{98}$ I would argue similarly that to understand the history of social mobility in nineteenth-century British society, to understand the rigidity that statistical analyses have uncovered, we need to understand the effort put in by families like the Heywoods into resisting fluidity, into shoring up their position, into social immobility. ${ }^{99}$

Focusing on the efforts of the Heywoods to transmit goods and character to their offspring also reveals that children - though invisible in the histories that chart the development of these family businesses - were there all along. But the realization of their adults' aspirations also required the older generation to inculcate in children a family culture that valued effort - whether in the pursuit of musical display or business success. The habits of industry, of civic responsibility, of correct behaviour, of bodily discipline must be fostered in children from the outset. This required financial but also emotional investment in those who would carry forth their aspirations. It also imposed a burden of expectation on children, the costs of which are sometimes perceptible at moments of tension, but which for the most part we can only perceive indirectly through the expressions of frustration and impatience of their anxious elders.

\footnotetext{
${ }^{1}$ This research was generously supported by the John Fell Fund, Oxford. I would like to thank Eve Worth, Kathryn Gleadle, and the Cultural and Social History reviewers for offering helpful advice on early drafts. I am grateful to the attendees of the University of York History Research Seminar and the Modern British History Seminar, Oxford for their questions and suggestions.

${ }^{2}$ Bolton Archives Centre, ZHE 42/82 Robert Heywood [hereafter RH] to Henry Leigh, 20 May 1852
} 
${ }^{3}$ Autobiographical Notes written by Mary Haslam, Aug 11, 1911 \& Aug 11, 1917 (nee Heywood) my mother. Transcribed originally by W[illiam] H[aslam] Bolton Record Office ZHA 17/16, [written as a series of 'Pictures' Autobiographical notes: transcript in S. King, Women, Welfare and Local Politics 1880-1920 (Brighton, 2006) p.202. Hereafter Haslam, 'Autobiographical notes'.

${ }^{4}$ Robert Heywood is the subject of a short biography, W. E. Brown, Robert Heywood of Bolton, 1786-1868 (Bradford, 1970). The family's papers are conserved in the Bolton Archives Centre: ZHE 1-71 (1738-1911).

${ }^{5}$ On Haslam's public life, see King, Women, Welfare and F. Moore, "'A band of public-spirited women": middle-class female philanthropy and citizenship in Bolton, Lancashire before 1918', Transactions of the Institute of British Geographers, (2016) 41, pp. 149-62.

${ }^{6}$ W.H. Sewell, Structure and Mobility: Men and Women of Marseille 1820-1870 (Cambridge, 1985);

A. Miles, Social Mobility in Nineteenth and Early Twentieth-century England (London, 1999); $\mathrm{H}$. Kaelbe, Social Mobility in the Nineteenth and Twentieth Centuries. Europe and America in comparative perspective, (Leamington Spa, 1985).

${ }^{7}$ J.A. Banks, Prosperity and Parenthood (London, 1969), pp.197-201. S. Szreter, Fertility, Class and Gender in Britain, 1860-1940 (Cambridge, 1996); J. Van Bavel, S. Morrel, B. Van de Putte, K Matthijs, 'Family size and intergenerational social mobility during the fertility transition', Demographic Research 24 (2011) pp.313-344.

${ }^{8}$ L.P. Moch, N. Folbre, D. Scott Smith, L.L. Cornell, L. A. Tilly, 'Family Strategy: a dialogue', Historical Methods, 20 (1987) 113-125. Hannah Barker similarly emphasises the need to think critically about the notion of family strategy, emphasizing the internal power-dynamics of family decision making. $\mathrm{H}$. Barker, Family and Business during the Industrial Revolution, (Oxford, 2017), p. 13.

${ }^{9}$ S. Pooley 'Parenthood, Child-rearing and Fertility in England, 1850-1914' The History of the Family 18 (2013), p. 84.

${ }^{10} \mathrm{~J}$. Goldthorpe, C. Llewellyn, C. Payne, Social mobility and class structure in modern Britain (1980); G. Payne \& P. Abbott, 'Introduction', in Payne \& Abbott, The Social Mobility of Women: Beyond Male Mobility Models, (London, 1990) p.2

${ }^{11}$ S. Lawler, 'Getting Out and Getting Away': Women's Narratives of Class Mobility' Feminist Review, 63 (1999), 3-24; V. Walkerdine, 'Reclassifying Upward Mobility: Femininity and the Neo-Liberal Subject', Gender and Education, 15 (2003) pp.237-248; S. Friedman, 'Habitus Clivé and the Emotional Imprint of Social Mobility', The Sociological Review, 64 (2016), 129-147.

${ }^{12}$ D. Bertaux, P. Thompson 'Introduction', in and D. Bertaux, I. Bertaux-Wiame, 'Heritage and its lineage: a case history of transmission and social mobility over five generations' in Bertaux \& Thompson (eds) Pathways to Social Class: A qualitative approach to social mobility (Oxford, 1997), p.6, and pp. 62-97

${ }^{13} \mathrm{~S}$. Nenadic, 'Businessmen, the urban middle classes, and the 'dominance' of manufacturers in nineteenth-century Britain', Economic History Review, 44 (1991) 66-85.

${ }^{14}$ A. Howe, The Cotton Masters, 1830-1860 (Oxford, 1984), pp.61-3.

${ }^{15} \mathrm{~F}$. Crouzet, The First Industrialists: the problem of origins (Cambridge 1985); K. Honeyman, Origins of Enterprise: Business leadership in the Industrial Revolution (1982); Howe, Cotton Masters; B. Lewis, The middlemost and the mill towns: bourgeois culture and politics in Early industrial England (Stanford, 2002)

${ }^{16}$ Biographical details of the Heywood family from Brown, Robert Heywood; King, Women, welfare; Genealogical and Census data research through Ancestry.co.uk.

${ }^{17}$ R. J. Morris, Men, Women and Property in England, 1780-1870 (London, 2006); A.J.

Owens, 'Inheritance and the Life-Cycle of Family Firms in the Early Industrial Revolution', Business History, 44 (2001), 21-46.' p. 43; Barker, Family and Business; A. Popp, Entrepreneurial families: business, marriage and life in the early 19thC (London, 2012). Thus, for the sake of simplicity, in the paragraph above I have referred to the 'Heywood enterprises', but this conceals the complexity of the processes by which branches of the business were constituted and re-constituted at different 
stages of the family's history in line with the needs of different generations: this was not a singular dynastic 'firm'. In line with A.J. Owens' findings, Owens, 'Inheritance and the Life-Cycle', p.43

${ }^{18}$ Morris, Men, Women and property, pp.367-8

${ }^{19}$ C. Parkes, Children's literature and capitalism: fictions of social mobility in Britain, 1850-1914

(Basingstoke, 2012) is the exception, but the focus is on literary and ideological constructions of the child as the ideal socially mobile subject in a capitalist society.

${ }^{20} \mathrm{~J}$. Bailey, Parenting in England 1760-1830: emotion, identity and generation (Oxford, 2012); H.

French \& M. Rothery, Man's estate: landed gentry masculinities (Oxford, 2012); A. Popp,

Entrepreneurial families, p.2.

${ }^{21}$ L. Wolff, 'Childhood and the Enlightenment: the complications of innocence' in P. Fass (ed.)

Childhood in the Western World (London, 2013), p.89; Barker, Family and Business, Ch.3; J. Bailey,

Parenting in England 1760-1830: Emotion, Identity and Generation (Oxford, 2012), Ch.7.

${ }^{22}$ See also Simon Gunn, 'Translating Bourdieu: cultural capital and the English middle class in

historical perspective', British Journal of Sociology, 56 (2005) p.63.

${ }^{23}$ Gunn, 'Translating Bourdieu'; Bertaux \& Thompson, Pathways, p.19; M. Savage \& F. Devine, 'The cultural turn, sociology and class analysis', in F. Devine, M. Savage, J. Scott, R. Crompton, Rethinking Class: Culture, Identities and Lifestyles (London, 2005), p.13-16.

${ }^{24}$ Bertaux \& Thompson, 'Introduction' p.20.

$25 \mathrm{~J}$. Tosh, 'Keighley to St-Denis: Separation and Intimacy in Victorian Bourgeois Marriage', History Workshop Journal, 40 (1995), p.193.

${ }^{26}$ C. Frank Law, Literature and the transmission of culture (London, 2010)

27 J.S. Mill, Principles of Political Economy (1884)

${ }^{28} \mathrm{~J}$. Tosh, A Man's place. Masculinity and the Middle-Class home in Victorian England (London, 1999), p.112; J.A. James, quoted in L. Davidoff \& C. Hall, Family Fortunes. Men and women of the English middle class 1780-1850 ( $2^{\text {nd }}$ edn. London, 2002), p.109

${ }^{29}$ M. Finn, The character of credit: personal debt in English culture 1740-1914 (Cambridge, 2003); K. Tawny Paul, 'Credit and masculinity in urban commerce: Edinburgh, c.1710-70' Economic History Review, 66 (2013); S. Collini, Public Moralists. Political Thought and Intellectual Life in Britain 18501930 (1991), p.94-97.

${ }^{30} \mathrm{R}$. Watts, 'The Unitarian contribution to the development of female education 1790-1850' History of Education, 9 (1980), p.275; C. Smith, I. Higginson, P. Wolstenholme, " "Avoiding equally extravagance and parsimony"; the moral economy of the ocean steamship' Technology \& Culture, 44 (2003) p.446.

${ }^{31}$ ZHE 67/8 Will of Robert Heywood, May 1855.

${ }^{32}$ Owens, 'Property, gender and the life course' Social History, 6 (2001) 299-317; Barker, Family and Business, p.50.

${ }^{33}$ Morris, Men, Women and property, p.369

${ }^{34}$ Haslam, 'Autobiographical notes' p.201.

${ }^{35}$ ZHE 26/3, Notebook of RH, Note of letter to Noah Makinson, $4^{\text {th }}$ Feb 1840; ZHE 35/44 Hannah McKeand [hereafter HM] to Robert Heywood, 24 Feb 1839.

${ }^{36}$ Morris, Men, Women and Property; A.J. Owens, 'Keeping it in the family: inheritance and 'wealthfare' in Victorian and Edwardian Britain' Inaugural Lecture, 11 Oct 2017, V\&A Museum of Childhood, https://www.youtube.com/watch?v=w0c0QB6MnIU

${ }^{37} \mathrm{~T}$. Piketty, Capital in the $21^{\text {st }}$ Century, (2014), Chs. 10 \& 11.

${ }^{38}$ The Heywood papers contain five documents dated from a twenty-year period relating to the distribution of Robert Heywood's property alone.

${ }^{39} \mathrm{ZHE} 43 / 63 \mathrm{HM}$ to RH, 9 Dec 1847.

${ }^{40} \mathrm{ZHE} 35 / 44 \mathrm{HM}$ to RH, 24 Feb 1849.

${ }^{41} \mathrm{ZHE} 43 / 64 \mathrm{HM}$ to RH, $29 \mathrm{Dec} 1847$.

${ }^{42}$ ZHE 72/42 Indenture $3^{\text {rd }}$ Jan 1851 between Elizabeth Rothwell and Robert Heywood.

${ }^{43}$ Howe, Cotton Masters, p.35. 
${ }^{44}$ R.H. Trainor, 'The gentrification of Victorian and Edwardian industrialists' in A.L. Beier, D. Cannadine \& J. Rosenheim (eds.) The First Modern Society (Cambridge, 1989), pp.180-1.

${ }^{45}$ M. Wiener, English culture and the decline of the industrial spirit, 1850-1980 (1981) Ch.7; W.D. Rubinstein, 'New men of wealth and the purchase of land in 19thC Britain, Past \& Present, (1981) $125-47$, challenged by T. Nicholas, 'Businessmen and land ownership in the late 19thC' Economic History Review (1999) 27-44.

${ }^{46}$ ZHE 47/90 RH to Miss Makison, 10 Feb 1851.

${ }^{47} \mathrm{ZHE} 71 / 52$ Extract from diaries of RH, entries for Oct 1850-May 1851.

${ }^{48}$ ZHE 47/90 RG to Miss Makison, 10 Feb 1851. M.B. Rose found similar motivations animating the purchase of land by the Greg family in Cheshire, M.B. Rose, The Gregs of Quarry Bank Mill (Cambridge, 1986), p.59.

${ }^{49}$ ZHE 29/18 John McKeand Snr to RH, 8 Jun 1833.

${ }^{50}$ ZHE 67/8 Codicil of will of Robert Heywood, February 1857.

${ }^{51}$ See R. Holt \& A. Popp, 'Emotion, succession and the family firm: Josiah Wedgwood \& Sons' Business History, (2013) 55/6 892-909 and S. Gunn, The Public Culture of the Victorian Middle Class (Manchester, 2000), pp.24-5 on the ways in which cultural consumption was used as a means of distinction and identification.

${ }^{52}$ The cohort of children born in 1831 was the first where over $3 / 5$ reached 25 years. M. Anderson, 'What is new about the modern family' in M. Drake (ed) Time, family and community: perspectives on family and community history (1994), p. 76.

${ }^{53}$ ZHE 41/97 and 41/100 HM to RH, October 1845.

${ }^{54}$ ZHE40/10 copy of letter from RH to JH Mckeand, 23 July 1844.

${ }^{55}$ M. Finn, The character of credit: personal debt in English culture 1740-1914 (Cambridge, 2003), p.21.

${ }^{56}$ For details of RH's public life, see Moore Robert Heywood, Chs 3-6.

${ }^{57}$ Haslam, 'Autobiographical recollections', p.199.

${ }^{58}$ King, Women, Welfare; Moore, 'A band of public-spirited women'.

${ }^{59}$ This echoes the pattern identified by Simon Gunn among the Manchester middle classes The Public culture of the Victorian Middle Class. Ritual and authority and the English Industrial City, 18401914 (Manchester, 2000), pp.2-3.

${ }^{60}$ ZHE 66/8-24 Bills from John Holland's school 1796-1802

${ }^{61} \mathrm{ZHE} 4 / 96 \mathrm{HM}$ to $\mathrm{RH}$, Oct 1845.

${ }^{62}$ ZHE 35/47 HM to RH, 28 Mar 1839.

${ }^{63} \mathrm{ZHE} 43 / 52 \mathrm{HM}$ to RH, Jan 1847

${ }^{64}$ PJ Miller, 'Women's education, self-improvement, and social mobility - a late 18thC debate' British Journal of Educational Studies, 20 (1972) 302-14

${ }^{65} \mathrm{~J}$. R. de Honey, Tom Brown's universe. The development of the public school in the nineteenth century, (London, 1977); Wiener, English culture pp.16-18.

${ }^{66}$ C. de Bellaigue, Educating women: schooling and identity in England and France (Oxford, 2007) p.142.; ZHE 71/52 Manuscript extract from RH diaries, entries for 10 Aug 1860, 5 Sept 1860.

${ }^{67} \mathrm{E}$. Robinson, 'Training captains of industry: the education of Matthew Robinson Boulton, 17701842, and the younger James Watt, 1769-1848', 10 (1954) Annals of Science, provides another example of industrial families whose educational choices were directed more by a belief in the value of instruction and certain practical skills than by social emulation. I am indebted to Catherine Sloan for fruitful discussions on the question of educational traditions in the North West of England. C.G. Sloan, 'The school magazine in England, 1850-1902' University of Oxford D.Phil. 2019, Ch.4. ${ }^{68}$ ZHE43/53 HM to RH 15 Jan 1847; ZHE 43/53 HM to RH 20 Jan 1847.

${ }^{69} \mathrm{~L}$. Davidoff, 'The role of gender in the 'first industrial nation' Agriculture in England, 1780-1850' in R. Crompton \& M. Mann (eds) Gender and Stratification (London, 1986), p.192; S. Gunn, 'Translating Bourdieu', p.55. 
${ }^{70}$ See J. Howarth 'Public schools, safety nets and educational ladders' Oxford Review of Education, 11 (1985) 59-71 for the ways in which girls' education was seen as an insurance against downward mobility in the later nineteenth Century.

${ }^{71}$ I. Lescent-Gilles, 'Les élites industrielles britanniques', Histoire, Economie et Société, 17 (1998) 157-188.

72 Tosh, Man's place, p.112.

${ }^{73}$ R. Watts, Gender, power, and the Unitarians in England, 1760-1860, (1998).

${ }^{74}$ ZHE 26/3 RH to Jacob Brettell, July 61838.

${ }^{75} \mathrm{U}$. Jensen, 'Mrs Gaskell's Anxiety' in U. Frevert (ed) Learning how to feel: children's literature and the history of emotional socialisation, 1870-1970 (Oxford, 2014), p.22.

${ }^{76}$ Oxford Dictionary of National Biography: John Relly Beard (1800-1876);

77 On Brooke House and Mrs Lalor see Bellaigue Educating women, pp.106, 142.

${ }^{78}$ W.E. Brown, History of Bolton School (Bolton, 1976), p.88.

${ }^{79}$ Haslam, 'Autobiographical notes' p. 200.

${ }^{80} \mathrm{ZHE} 45 / 75 \mathrm{MM}$ to $\mathrm{RH}, 15$ Oct 1849.

${ }^{81}$ ZHE 66/8 Robert Heywood's Instruction with John Holland, Winter-Midsummer 1796

82 ZHE 35/42 HM to RH, 19 Jan 1839.

${ }^{83}$ ZHE 38/52 HM to RH, 19 May 1842.

${ }^{84}$ ZHE 38/59 RH to Mr Philips 24 July 1842.

${ }^{85}$ ZHE 71/52 Extract from diaries of RH.

${ }^{86}$ ZHE41/94 RM to RH, 2 Sept 1845.

${ }^{87}$ Bailey, Parenting in England, p.184

${ }^{88}$ Haslam, Autobiographical notes' p. 200

${ }^{89}$ ZHE 71/52 Extract from diaries of RH, entry for 20 Jan 1862.

${ }^{90}$ ZHE 47/90 Note of letter of RH to Miss Makinson, 10 Feb 1851.

${ }^{91}$ ZHE 26/3 Note of letter of RH to Noah Makinson, 4 Feb 1840.

${ }^{92}$ ZHE 40/10 Note of a letter of RH to JH McKeand, 23 July 1844;

${ }^{93}$ ZHE 20/2 Note of letter of RH to unnamed cousins, 1824.

${ }^{94}$ Gunn, 'Translating Bourdieu', p.61.

${ }^{95}$ Haslam, 'Autobiographical reflections', p.200.

${ }^{96}$ Ibid, p.201.

${ }^{97}$ Morris, Men, Women and Property; Barker, Family and Business; Owens, 'Property'; Trainor, 'Gentrification'.

${ }^{98}$ D. Verhoeven \& S, Palmer, 'Women aren't the problem in the film industry, men are' The Conversation, Nov 15, 2016 https://theconversation.com/women-arent-the-problem-in-the-film-industry-men-are-68740 (last accessed 18.12.2018)

${ }^{99}$ Miles, Social mobility; D. Mitch, 'Inequalities which every one may remove": occupational recruitment, endogamy and the homogeneity of social origins in Victorian England' in A. Miles \& D. Vincent (eds), Building European Society: Occupational Change and Social Mobility in Europe, 18401940, (Manchester, 1993) 140-64. 